\title{
A new flea of the genus Ctenidiosomus (Siphonaptera, Pygiopsyllidae) from Salta Province,Argentina
}

\author{
M. Fernanda López-Berrizbeitia ${ }^{1,2}$, Michael W. Hastriter ${ }^{3}$, \\ Rubén M. Barquez ${ }^{1,4}$, M. Mónica Díaz ${ }^{1,2,4}$
}

I PCMA (Programa de Conservación de los Murciélagos de Argentina), y PIDBA (Programa de Investigaciones de Biodiversidad Argentina), Facultad de Ciencias Naturales e Instituto Miguel Lillo, Universidad Nacional de Tucumán, Miguel Lillo 205, (4000) Tucumán, Argentina 2 Fundación Miguel Lillo 3 Monte L. Bean Life Science Museum, Brigham Young University, 290 MLBM, PO Box 20200, Provo, UT 84602-0200, USA 4 CONICET (Consejo Nacional de Investigaciones Cientificas y Técnicas), Argentina

Corresponding author: M. Fernanda López-Berrizbeitia (mflopezberri@hotmail.com)

Academic editor: Pavel Stoev | Received 28 March 2015 | Accepted 20 June 2015 | Published 7 July 2015

http://zoobank.org/AE766E2F-7B20-49FB-80A6-903EB3B57C48

Citation: López-Berrizbeitia MF, Hastriter MW, Barquez RM, Díaz MM (2015) A new flea of the genus Ctenidiosomus (Siphonaptera, Pygiopsyllidae) from Salta Province, Argentina. ZooKeys 512: 109-120. doi: 10.3897/zookeys.512.9713

\section{Abstract}

A new species of flea of the genus Ctenidiosomus Jordan, 1931 (Siphonaptera: Pygiopsyllidae) is described from Phyllotis osilae J. A. Allen, 1901, from Salta Province, Argentina. This is the first time that Ctenidiosomus has been recorded in Argentina. A key to species of males of Ctenidiosomus is presented.

\section{Resumen}

Una nueva especie de pulga del género Ctenidiosomus Jordan, 1931 (Siphonaptera: Pygiopsyllidae) es descripta de Phyllotis osilae J. A. Allen, 1901, de la provincia de Salta, Argentina. Cabe mencionar que es la primera vez que el género Ctenidiosomus ha sido registrado en Argentina. Se ofrece una clave para los machos de las especies de Ctenidiosomus.

\section{Keywords}

Ctenidiosomus austrinus, identification key, Phyllotis osilae 


\section{Introduction}

Ctenidiosomus is the only flea genus of the family Pygiopsyllidae (Pygiopsylloidea) that occurs in the Western Hemisphere and is restricted to South America. All others are found in the Australian Region. The current distribution of the genus Ctenidiosomus extends from Venezuela to southern Peru (Johnson 1957, Mardon 1981) and includes four species: C. perplexus Tipton \& Machado-Allison, 1972, C. rex Johnson, 1957, C. spillmanni Jordan, 1931, and C. traubi Johnson, 1957. The latter species is known only in the female sex. During biodiversity studies of small mammals and birds of Northwestern Argentina, a new species of Ctenidiosomus was discovered and is described herein. The distribution of all species of Ctenidiosomus is presented on Fig. 14, and a key to known male Ctenidiosomus species is presented.

\section{Materials and methods}

Biodiversity surveys of birds and small mammals were conducted in the Monte desert of Mountains and Isolated Valleys, in Salta Province, Argentina between 1998 and 2001. Ectoparasites were collected and results of those collections will be published elsewhere at a later date; however, a single male specimen representing a new species of Ctenidiosomus was discovered during collections in May 1999 from a male Phyllotis osilae J. A. Allen, 1901 and is described herein. Other mammals examined during May 1999 included 34 rodents [26 specimens of Akodon Meyen, 1833, four Necromys lactens (Thomas, 1918), and four Phyllotis Waterhouse, 1837] captured with Sherman live traps baited with peanut butter and oats. All rodents were subjected to a thorough post-mortem visual examination and inspected for fleas which were removed with forceps. The single flea was prepared following conventional techniques for taxonomic identification. The images were prepared using an Olympus BX61 Compound Microscope, Olympus CC12 digital camera accompanied with an Olympus Microsuite ${ }^{\mathrm{TM}}$ B3SV program in the Monte L. Bean Life Science Museum, Brigham Young University, Provo, UT, U.S.A. The landmarks used to measure the flea are described in Hastriter and Eckerlin (2003). Anatomical terms were adapted from Rothschild and Traub (1971) and the classification given by Hastriter (2012) was followed. Mammal nomenclature follows Barquez et al. (2006), Gardner (2008) and Patton et al. (2015). Unless otherwise specified, counts of setae and ctenidiae comprise only one side of flea. The host specimen was deposited in the Colección Mamíferos Lillo (CML), Universidad Nacional de Tucumán and Fundación Miguel Lillo, while the holotype of the new species was deposited in the Annexes of the CML (CML 8044). 


\section{Taxonomy}

\section{Siphonaptera}

Pygiopsyllomorpha Medvedev, 1998

Pygiopsylloidea Medvedev, 1998

Pygiopsyllidae Wagner, 1939

\section{Ctenidiosomus austrinus López-Berrizbeitia, Hastriter \& Díaz, sp. n. http://zoobank.org/363CEFAB-D756-4E37-AC83-F016C7331551}

Figs $1-13$

Type material. Holotype: $\widehat{\delta}$, Argentina, Salta Province: $-15 \mathrm{~km}$ W Escoipe, on Provincial road No. 33, (2510'25.2"S; 6549'31.6"W), 2680m (Fig. 14), found on Phyllotis osilae, $17 \mathrm{~V}$ 1999, (CML 8044).

Diagnosis. The new species can be distinguished from all species of the genus by characteristics of the distal arm of S-IX and the clasper (basimere and telomere). These include the presence of a thick sclerotization along the dorsal margin of distal arm of S-IX (Fig. 5 and 9), and by an oblique angle on the dorso-caudal apex of P1 (process) of the basimere subtended by a deep sinus (Fig. 11). General facies of the aedeagus are most closely akin to those of C. spillmanni; however, the P1 of the basimere of the males of the three known species is rounded at the apex and the dorsal margin of distal arm of S-IX without sclerotizations (Jordan 1931, Johnson 1957, Tipton and Machado-Allison 1972), while in the new species the apex of P1 is oblique with deep sub-tending sinus and dorsal margin of distal arm with thick marginal sclerotization. Furthermore, $C$. austrinus is separable from $C$. rex and $C$. perplexus by the lateral lobe of aedeagus not extended into narrow process, a character shared with C. spillmanni.

Description. Head (Figs 1-3). Frons evenly rounded, thin sclerotization throughout. Preantennal area with two placoid pits, micro-punctuations scattered over surface; two vertical rows of setae: 5-6 small setae in anterior row and three longer setae in posterior row. Eye visible, sinuate, unpigmented. Antennal scape with 27-28 small lateral setae. Pedicel with nine setae, none extending onto clavus; clavus extended beyond antennal fossa. Maxilla acutely sharp; labial palpus of four segments (excluding palp bearing maxillary segment) (Fig. 2). Post-antennal area with three placoid pits; scattered micro-punctuations over surface and several minute triangular punctiform setae between three placoid pits. Occipital area with three rows of setae; anterior row oblique with three small setae; middle row with 4-5 small setae, and main row with seven long setae plus intercalaries.

Thorax. Pronotum with comb of 23 ctenidia (both sides) preceded by three rows of setae; anterior row with three medium setae, middle with 8-9 medium setae, and main row of nine long setae plus intercalaries. Meso- and metanota with a main row of eight setae plus intercalaries (Fig. 3). Mesosternum with long seta at lower margin. Mesepimeron with three long setae. Lateral metanotal area with single long seta at posterior margin. Pleural arch and ridge well developed. Metepisternum with three long 


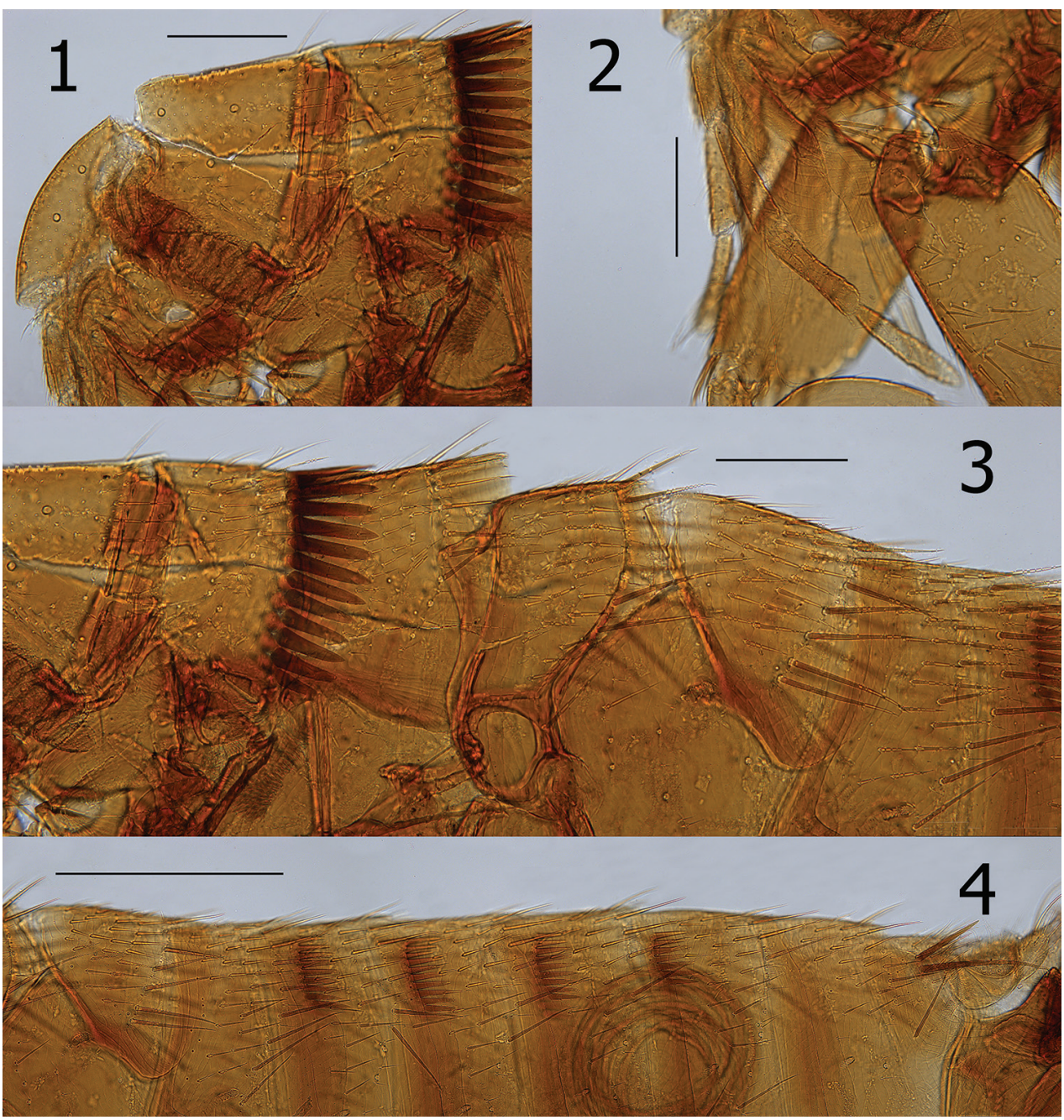

Figures I-4. Ctenidiosomus austrinus sp. n., male holotype. I Head and pronotum 2 Labial palpus and maxilla 3 Pronotum, mesonotum and metanotum 4 Abdominal tergites. Scale: $200 \mu \mathrm{m}$.

setae. Furca short and robust. Metepimeron with two rows of small setae (anterior with five, posterior with three). Rod-like abdominal link plate present as in all Pygiopsyllomorpha (Fig. 10).

Legs. Fore coxa with small setae scattered over surface, one distinct horizontal row of seven setae near apex, three stout anteroapical setae. Mesocoxa and hind coxa with small setae scattered on lower outer surface. Fore femora with 4-5 minute lateral setae and one long seta at femoro-tibial joint. Meso- and hind femoro-tibial joint with one short lateral and one long mesal seta. Margin of fore, meso- and hind tibiae with seven notches. Hind tibia bearing three setae (two long, one small) in penultimate notch. Long space between notch five and six, heavily sclerotized (Fig. 12). Distotarsomere of 


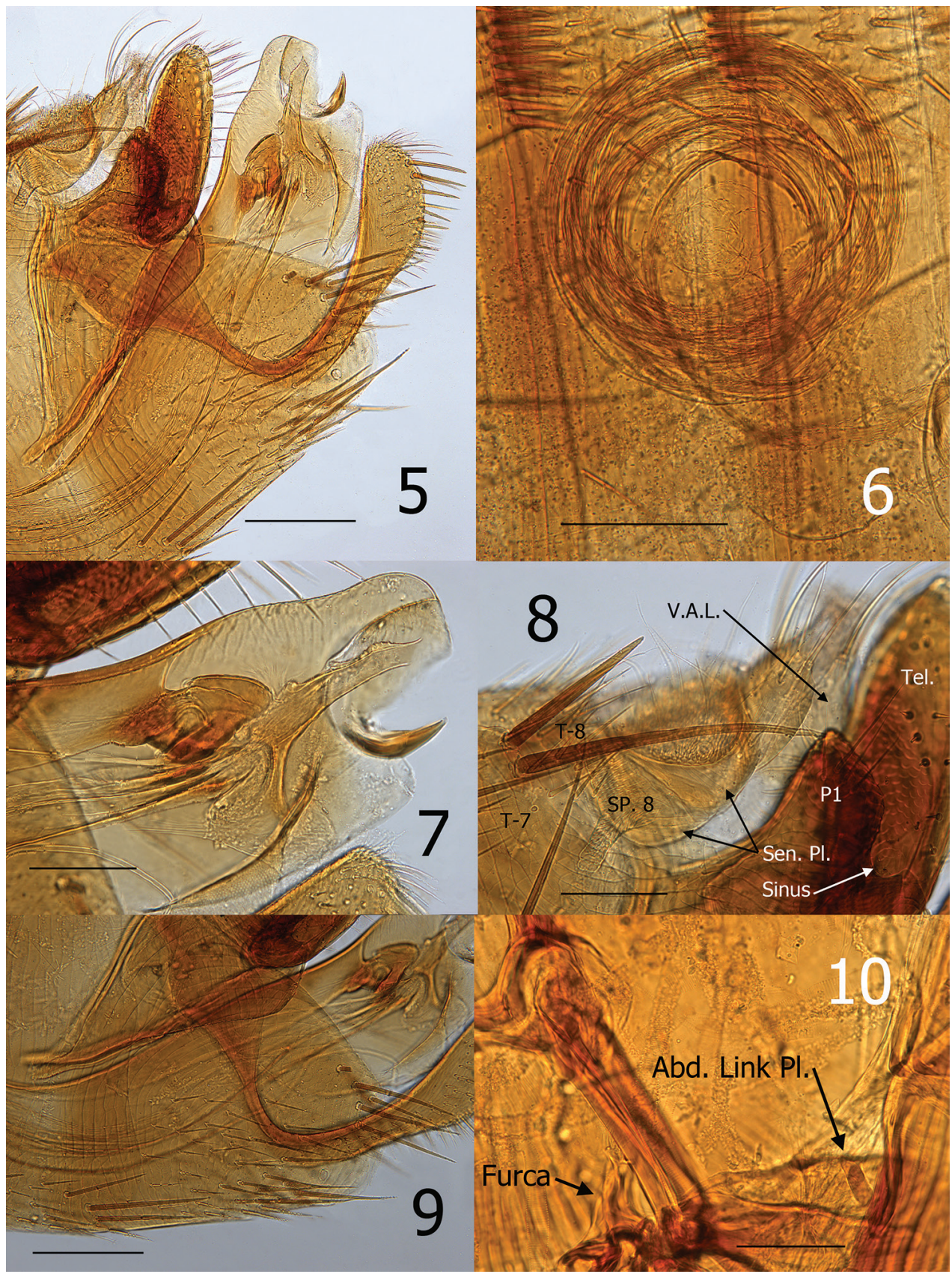

Figures 5-10. Ctenidiosomus austrinus sp. n., male holotype $\mathbf{5}$ Terminal segments $\mathbf{6}$ Penis rods $\mathbf{7}$ Apex of aedeagus 8 Sensilium and P1 of basimere 9 Sternum VIII 10 Abdominal link plate, furca and pleural ridge. Scale: $200 \mu \mathrm{m}(\mathbf{5}, \mathbf{6 ,} \mathbf{9}) ; 100 \mu \mathrm{m}(\mathbf{7}, \mathbf{8}, \mathbf{1 0})$. 


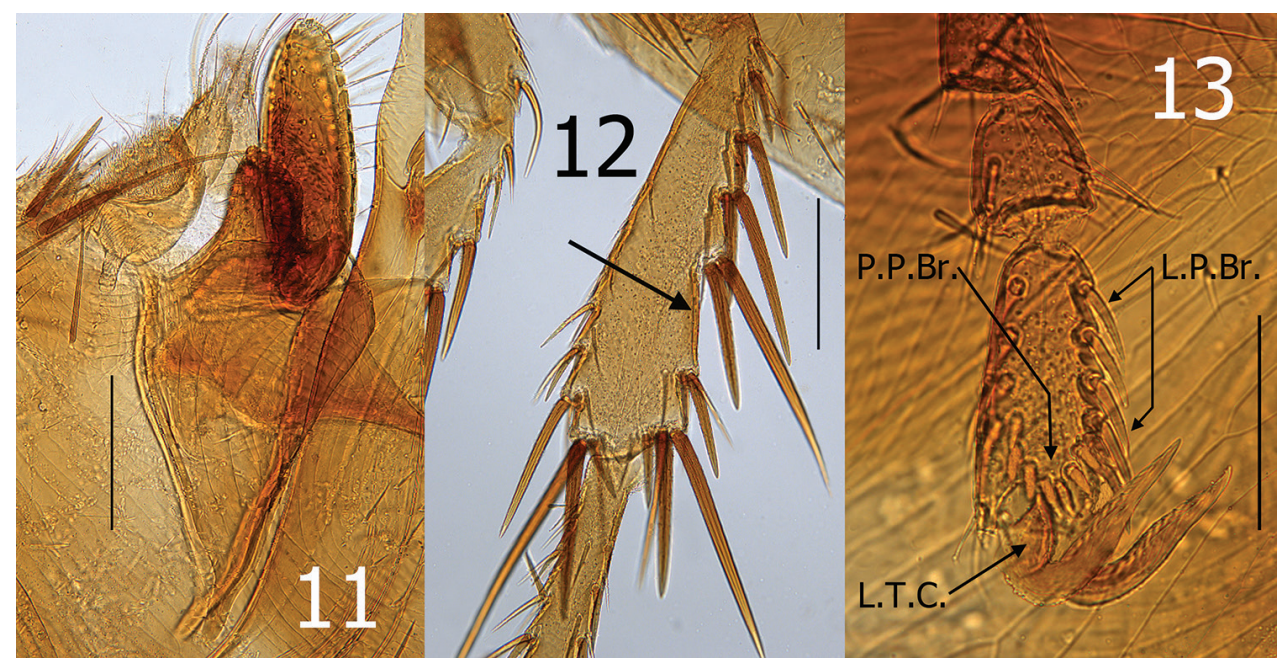

Figures I I-I3. Ctenidiosomus austrinus sp. n., male holotype I I Basimere and telomere I 2 Hind tibia I 3 Hind distotarsomere. Scale: $200 \mu \mathrm{m}$ (I I, I 2); $100 \mu \mathrm{m}$ (I3).

hind leg with five lateral plantar bristles and eight preapical plantar bristles arranged in semicircle (Fig. 13).

Unmodified Abdominal Segments. Ctenidial combs on terga II-V (T-II-V). The number of ctenidia on two sides as follows: T-II 18, T-III 20, T-IV 18, T-V 15 (Fig. 4). Two antesensilial bristles (Fig. 8).

Modified Abdominal Segments. Sensilium with 18 sensilial pits. Dorsal anal lobe with three long thin setae; ventral with single long seta. (Fig. 8). Tergum VIII with seven long setae at dorso-posterior margin (Fig. 9).

Apex of $\mathrm{P} 1$ of basimere with oblique angle on the dorsocaudal margin with deep sub-tending sinus, manubrium with convex anterodorsal margin and apically narrowed. Telomere narrowing gradually to rounded apex. Distal arm of sternum nine (S-IX) distinctly widened apically, with five to six larger setae interspersed with smaller setae on apical margin; dorsal margin with broad marginal sclerotization (Fig. 5). Aedeagus. Median dorsal lobe rounded apically. Lateral lobe nearly parallel with upper margin of median dorsal lobe to level of sclerotized inner tube, then expands caudally into a rounded lobe that envelops inner phallosome (Fig. 7). Long thin sclerite between sclerotized inner tube and ventral margin of phallosome. Minutely membranous pouch ventral to the thin sclerite and dorsal to a thinly sclerotized ventral keel. Ford's sclerites curved up; hyaline at base and sclerotized on apical half. Crescent sclerite with small satellite sclerite abutted against sclerotized inner tube. Sclerotized inner tube slightly narrowing towards apex; upper margin of apex longer than lower margin. Dorsal armature with minute undulations along distal half of sclerotized inner tube. Ventral armature absent. Aedeagal apodeme narrow; extending to sharp point curved upward at apex. Penis rods coiled multiple revolutions as a watch spring (Fig. 6).

Dimensions: Holotype male: $3.7 \mathrm{~mm}$ 


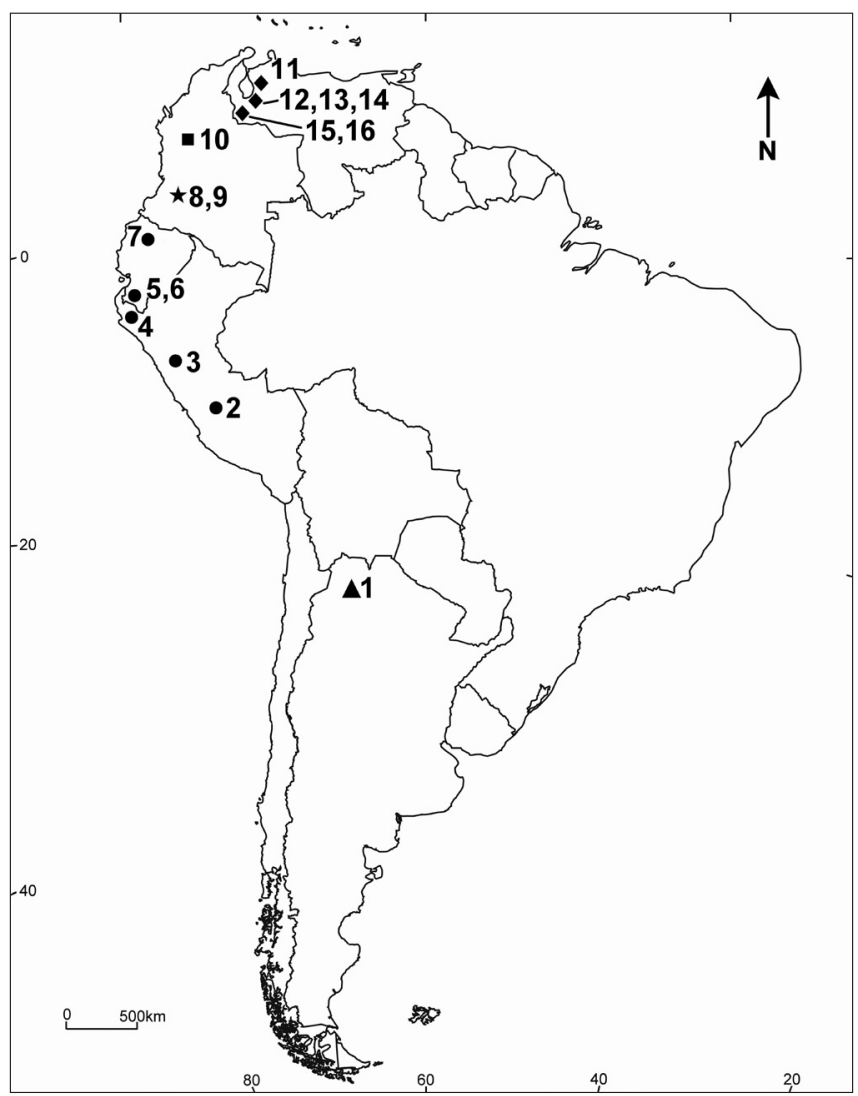

Figure 14. Distribution of the species of Ctenidiosomus. Ctenidiosomus austrinus: I Type locality: Argentina, Salta Province, Dept. Chicoana, app. 15 km W Escoipe, on Provincial road N³3 (2510'25.2"S; 6549'31.6"W), 2680 m. Ctenidiosomus spillmanni: 2 Peru, Dept. Junín, Huancayo Province, El Tambo (1201'37.88"S; 7512'46.46"W), 3327 m; 3 Peru, Depto. Ancasch, Huaylas Province, Hua-

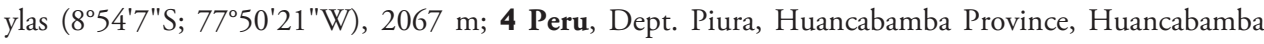
(5¹4'22"S; 79²6'59"W), 1930 m; 5 Ecuador, Loja Province (no specific locality) I; 6 Ecuador, Loja Province, Alamor (401'14.29"S; 8001'21.97"W), 1279 m. 7 Type locality: Ecuador, Pichincha Province (no specific locality). Ctenidiosomus rex: 8 Type locality: Colombia, Dept. Huila, San Agustin (1'52'39.20"N; 76 15'11.08"W), 1625 m; 9 Colombia, Dept. Huila, San Agustin, left bank of Rio Magdalena $\left(1^{\circ} 55^{\prime} 01.10^{\prime \prime N} ; 76^{\circ} 20^{\prime} 59.06^{\prime \prime W}\right), 1748 \mathrm{~m} \dagger$. Ctenidiosomus traubi: 10 Type locality: Colombia, Dept. Antioquia, Sonson $\ddagger$, 7 km E of Paramo (543'23.23"N; 75¹1'11.36"W), 2049 m. Ctenidiosomus perplexus: I I Type locality: Venezuela, Trujillo State, Trujillo Township, Trujillo, 14 km. E, near Misisi. $\left(9^{\circ} 21^{\prime} 51.23^{\prime \prime} \mathrm{N} ; 70^{\circ} 18^{\prime} 30.89^{\prime \prime} \mathrm{W}\right), 2210 \mathrm{~m}$. Other distribution records: I 2 Venezuela, Merida State, near Santa Rosa ( $8^{\circ} 53^{\prime} 52.11^{\prime \prime N}$; 70³6'55.77"W), 2040 m; I 3 Venezuela, Merida State, near Middle Refugio $\left(8^{\circ} 36^{\prime} 07.36 " \mathrm{~N}\right.$; 710.'17.00"W), $2550 \mathrm{~m}$; 14 Venezuela, Merida State, La Coromoto $\left(8^{\circ} 6^{\prime} 48.31^{\prime \prime N}\right.$; $\left.71^{\circ} 29^{\prime} 54.1^{\prime W}\right), 2500 \mathrm{~m} \$$. 15 Venezuela, Tachira State, San Cristobal Township, $35 \mathrm{~km} \mathrm{~S}$ and $22 \mathrm{~km} \mathrm{~W}$ of San Cristobal, Buena Vista (7'29'43.29"N; 72²6'52.45"W), 2386 m; 16 Venezuela, Tachira State, Buena Vista $\left(7^{\circ} 29^{\prime} 43.29^{\prime \prime N}\right.$; 72 $\left.26^{\prime} 52.45^{\prime \prime W}\right), 2386 \mathrm{~m}$; †The elevation was incorrectly cited as " $2300 \mathrm{~m}$ " in Johnson 1957; ¥The city was incorrectly cited as "Sanson" in Mardon 1981; \$ The elevation was incorrectly cited as "3170" in Tipton and Machado Allison 1972; I Both, the specific and unspecified localities are indicated by a point, the unspecified locality is placed in an approximate point. 
Table I. Hosts of the five species of Ctenidiosomus, actual name, and distribution are mentioned.

\begin{tabular}{|c|c|c|c|}
\hline- & HOSTS & & FLEAS \\
\hline Cited as & Current Valid Name & Distribution & \\
\hline \multicolumn{4}{|l|}{$\begin{array}{c}\text { Order Paucituberculata } \\
\text { Family Caenolestidae }\end{array}$} \\
\hline $\begin{array}{l}\text { Caenolestes obscurus } \$ \\
\text { Thomas, } 1895\end{array}$ & $\begin{array}{l}\text { Caenolestes fuliginosus } \\
\text { (Tomes, 1863) }\end{array}$ & $\begin{array}{c}\text { Andes of Colombia, Ecuador, and } \\
\text { northwestern Venezuela| }\end{array}$ & $\begin{array}{l}\text { Ctenidiosomus } \\
\text { traubi }\end{array}$ \\
\hline Order Rodentia & Order Rodentia & & \\
\hline Suborder Myomorpha & Suborder Myomorpha & & \\
\hline Family Cricetidae & Family Cricetidae & & \\
\hline $\begin{array}{l}\text { Subfamily } \\
\text { Sigmodontinae }\end{array}$ & $\begin{array}{c}\text { Subfamily } \\
\text { Sigmodontinae }\end{array}$ & & \\
\hline $\begin{array}{l}\text { Akodon mollis\$ } \\
\text { Thomas, } 1894\end{array}$ & $\begin{array}{c}\text { Akodon mollis Thomas, } \\
1894\end{array}$ & $\begin{array}{l}\text { Northwestern Peru to northern Ecuador, } \\
\text { from sea level to above } 4900 \mathrm{~m}\end{array}$ & C. spillmanni \\
\hline $\begin{array}{l}\text { Anotomys trichotis } \$ \\
\text { Handley, } 1976\end{array}$ & $\begin{array}{l}\text { Chibchanomys trichotis } \\
\text { (Thomas, 1897) }\end{array}$ & $\begin{array}{l}\text { Elevation between } 2400 \text { and } 2900 \mathrm{~m} \text { in the } \\
\text { Tachira Andes of western Venezuela and } \\
\text { Cordillera Oriental near Bogotá, Colombia\# }\end{array}$ & C. perplexus \\
\hline $\begin{array}{l}\text { Oryzomys albigularis } \dagger \neq \\
\text { (Tomes, 1860) }\end{array}$ & $\begin{array}{l}\text { Nephelomys meridensis\# } \\
\quad \text { (Thomas, 1894) }\end{array}$ & $\begin{array}{c}\text { Colombia and northern portion of Sierra } \\
\text { de Mérida, Trujillo State, Venezuela, } 1000- \\
4000 \mathrm{~m} \dagger \dagger\end{array}$ & C. perplexus; C.rex \\
\hline $\begin{array}{l}\text { Oryzomys minutus } \\
\text { Thomas, } 1917\end{array}$ & $\begin{array}{l}\text { Microryzomys minutus } \\
\quad \text { (Tomes, 1860) }\end{array}$ & $\begin{array}{l}\text { Middle and high elevations in the northern } \\
\text { and central Andes, including the Caribbean } \\
\text { Coast Ranges and Mérida Andes of } \\
\text { Venezuela; also in Colombia, Ecuador, Peru, } \\
\text { and Bolivia, 800-4265 m㧊 }\end{array}$ & C. perplexus \\
\hline $\begin{array}{l}\text { Oryzomys xanthaeolus } \$ \\
\text { Thomas, } 1894\end{array}$ & $\begin{array}{l}\text { Aegialomys xanthaeolus } \\
\text { (Thomas, 1894) }\end{array}$ & $\begin{array}{l}\text { Coasts and mountains of southwestern } \\
\text { Ecuador and southeastern Peru, above } \\
2500 \mathrm{~m} \dagger \dagger\end{array}$ & C. spillmanni \\
\hline $\begin{array}{l}\text { Phyllotis osilae } \\
\text { J. A. Allen, } 1901\end{array}$ & $\begin{array}{l}\text { Phyllotis osilae J. A. } \\
\quad \text { Allen, } 1901\end{array}$ & $\begin{array}{l}\text { From Southern Peru to northwestern } \\
\text { Argentina, along the eastern Altiplano and } \\
\text { Andean slopes, } 500-4000 \mathrm{~m} \$ \$\end{array}$ & C. austrinus sp. n. \\
\hline $\begin{array}{l}\text { Rhipidomys venustus } \$ \\
\text { Thomas, } 1900\end{array}$ & $\begin{array}{l}\text { Rhipidomys venustus } \\
\text { Thomas, } 1900\end{array}$ & $\begin{array}{c}\text { Endemic of Venezuela, Andes of Mérida and } \\
\text { Trujillo, mostly above } 2000 \mathrm{~m} \|\end{array}$ & C. perplexus \\
\hline Rhipidomys†sp. & Rhipidomys sp. & - & C. rex \\
\hline $\begin{array}{l}\text { Thomasomys cinereus } \$ \\
\text { (Thomas, 1882) }\end{array}$ & $\begin{array}{l}\text { Thomasomys cinereus } \\
\text { (Thomas, 1882) }\end{array}$ & $\begin{array}{l}\text { Northwestern Peru, west of the Río } \\
\text { Marañon, } 1198 \text { to } 3100 \mathrm{~m} \mathbf{g g}\end{array}$ & C. spillmanni \\
\hline $\begin{array}{c}\text { Thomasomys hylophilus } \ddagger \\
\text { Osgood, } 1912\end{array}$ & $\begin{array}{l}\text { Thomasomys hylophilus } \\
\text { Osgood, } 1912\end{array}$ & $\begin{array}{l}\text { Cordillera Oriental, in eastern Colombia, } \\
\text { and Cordillera de Mérida in western } \\
\text { Venezuelagg }\end{array}$ & C. perplexus \\
\hline $\begin{array}{l}\text { Thomasomys laniger } \neq \\
\text { (Thomas, 1895) }\end{array}$ & $\begin{array}{l}\text { Thomasomys emeritus } \\
\text { Thomas, } 1916\end{array}$ & $\begin{array}{l}\text { Venezuelan Andes in the departments of } \\
\text { Mérida and Trujillo, 2090-3550 m } 99\end{array}$ & C. perplexus \\
\hline Thomasomys sp. $\dagger$ & Thomasomys sp. & $\longrightarrow$ & C. rex \\
\hline $\begin{array}{l}\text { Thomasomys lugens } \ddagger \\
\text { Osgood, } 1933\end{array}$ & $\begin{array}{l}\text { Aepeomys lugens } \\
\text { (Thomas, 1896)\| }\end{array}$ & $\begin{array}{l}\text { Mérida Andes of Venezuela (Tachira and } \\
\text { Mérida States), 1990-3500 mgg }\end{array}$ & C. perplexus \\
\hline Subfamily Tylomyinae & Subfamily Tylomyinae & & \\
\hline Neomys sp. $\$$ & $\begin{array}{c}\text { Tylomys mirae Thomas } \\
189999\end{array}$ & 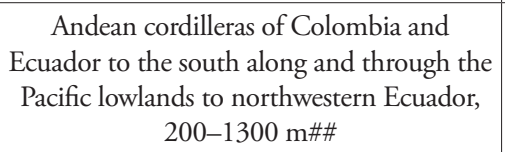 & C. spillmanni \\
\hline
\end{tabular}




\begin{tabular}{c|c|c|c}
\hline- & HOSTS & & FLEAS \\
\hline Cited as & Current Valid Name & Distribution & \\
\hline $\begin{array}{c}\text { Suborder } \\
\text { Hystricomorpha }\end{array}$ & $\begin{array}{c}\text { Suborder } \\
\text { Hystricomorpha }\end{array}$ & & \\
\hline Family Caviidae & Family Caviidae & & \\
\hline Cavia sp. $\$$ & Cavia sp. & - & C. spillmanni \\
\hline
\end{tabular}

$\dagger$ Cited in Johnson 1957; $¥$ Cited in Tipton and Machado-Allison 1972; \$ Cited in Mardon 1981.

| According to Timm and Patterson 2008. At present, Caenolestes obscurus is considered synonym of C. fuliginosus; I According to Pardiñas et al. 2015; \# According to Voss 2015; †† According to Percequillo 2015a,b. Currently, Oryzomys albigularis is synonym of many species of the genus Nephelomys; we believe the cited species is $N$. meridensis because of its distribution; $\neq \neq$ According to Carleton 2015; $\$ \$$ According to Steppan and Ramirez 2015; || According to Tribe 2015; g9 According to Pacheco 2015a,b, Thomasomys emeritus was synonym of $T$. laniger, but is currently considered a new and valid species, We determined that the cited species corresponds to T. emeritus by its distribution; \#\# According to AlvarezCastañeda 2015, we considered the cited hosts as Tylomys mirae since it is the only known species of genus distributed in South America.

Etymology. The specific epithet is derived from the Latin term austrinus or "southern" because this new species represents the southern-most record of any known species of Ctenidiosomus.

Remarks. The single male holotype was collected from a juvenile male specimen of the sigmodontine rodent, Phyllotis osilae, during the dry season in the month of May. Ctenidiosomus perplexus and C. rex, were recorded on sigmodontines rodents, while $C$. spillmanni was collected not only on sigmodontine rodents but also on Hystricomorpha rodents, and C. traubi on Caenolestes obscurus, Order Paucituberculata (Johnson 1957, Mardon 1981) (Table 1).

The type locality of Ctenidiosomus austrinus corresponds to the Ecoregion "Monte desert of Mountains and Isolated valleys" (Burkart et al. 1999), where the vegetation is characterized by small and medium shrubs and cacti called "cardones" (Trichocereus atacamensis). Also, some scattered trees typical of the ecoregions "algarrobos" (Prosopis alba) are present. The soil is stony, and formed by rocks of all sizes (Burkart et al. 1999). Similar to all other species of Ctenidiosomus, the new species was collected at a high elevation ( $2680 \mathrm{~m}$ above sea level) (see Fig. 14 for the localities). With this report, the geographical distribution of the genus Ctenidiosomus is extended $-2600 \mathrm{~km}$ further South from its previously known southern limits of El Tambo, Huancayo Province, Department Junín, Peru (Mardon 1981). The presence of this species in Bolivia is highly probable due to its location between Peruvian and Argentine records.

There have been far fewer species of fleas described from northwestern Argentina than other regions of the country (e.g. Patagonia; see Hastriter and Sage 2009, 2011, Sanchez and Lareschi 2014), primarily due to the lack of sampling efforts. We predict that with increased surveillance in Northern Argentina and bordering countries (Bolivia, Paraguay), numerous new taxa will be discovered. Although in recent years, the sampling of small mammals has increased in Northwestern Argentina (Díaz and 
Barquez 2007, Ojeda et al. 2008, Ferro and Barquez 2009, Díaz and Barquez 2009, Jayat and Ortiz 2010), this region still represents one of the least studied areas in South America relative to Siphonaptera and other ectoparasites.

\section{Key to males of Ctenidiosomus species}

Although females of $C$. austrinus are not known, we can affirm that our specimen does not represent the currently unknown male of $C$. traubi by the following characters as evidence of its distinctiveness as a new taxon when compared to the female of $C$. traubi: 1) two antesensilial bristles on T-VII (three in $C$. traubi), 2) presence of a distinct horizontal row of seven setae near apex of fore coxa, 3 ) three stout antero-apical setae on apex of fore coxa, 4) three setae ( 2 large, 1 small) in penultimate notch of hind tibia, and 5) pronotum with three rows of setae (two in C. traubi).

For identification of Ctenidiosomus females, refer to the key by Mardon (1981).

1 Ford's sclerite of aedeagus curved down C. rex

- $\quad$ Ford's sclerite curved up 2

2 P1 of basimere rounded at apex; dorsal margin of distal arm of S-IX without sclerotizations 3

- $\quad$ P1 of basimere oblique at apex with deep sub-tending sinus; dorsal margin of distal arm with thick marginal sclerotization. C. austrinus sp. $\mathbf{n}$.

3 Lateral lobe of aedeagus extended into long narrow process ...... C. perplexus - $\quad$ Lateral lobe not extended into narrow process, but forming a near right angle at apex

C. spillmanni

\section{Acknowledgements}

The field trip was funded by CIUNT (Centro de Investigaciones de la Universidad Nacional de Tucumán), CONICET, PID 4963; additional support was received from grants of Michael A. Mares from the National Science Foundation (DEB-9870184 and BSR 8906665) and the National Geographic Society (6520-9).

\section{References}

Alvarez-Castañeda ST (2015) Subfamily Tylomyinae. In: Patton JL, Pardiñas UFJ, D’Elía G (Eds) Mammals of South America - Volume 2, Rodents. The University of Chicago Press, Chicago, 683-688.

Barquez RM, Díaz MM, Ojeda RA (2006) Mamíferos de Argentina. Sistemática y distribución. Sociedad Argentina para el Estudio de los Mamíferos (SAREM), Mendoza, Argentina, 359 pp. 
Burkart R, Bárbaro NO, Sanchez RO, Gomez DA (1999) Eco-regiones de la Argentina. Administración de Parque Nacionales. Programa Desarrollo Institucional Ambiental, Buenos Aires.

Carleton MD (2015) Genus Microryzomys. In: Patton JL, Pardiñas UFJ, D’Elía G (Eds) Mammals of South America - Volume 2, Rodents. The University of Chicago Press, Chicago, 355-359.

Díaz MM, Barquez RM (2007) The wild mammals of Jujuy Province, Argentina: systematics and distribution. In: Kelt DA, Lessa EP, Salazar-Bravo JA, Patton JL (Eds) The quintessential naturalist: honoring the life and legacy of Oliver Pearson. University of California Publications in Zoology 134: 417-578.

Díaz MM, Barquez RM (2009) Primer registro de Micronycteris microtis (Phyllostomidae, Phyllostominae) para la Argentina. Chiroptera Neotropical 15: 461-465.

Ferro LI, Barquez RM (2009) Species Richness of Nonvolant Small Mammals along Elevational Gradients in Northwestern Argentina. Biotropica 41: 759-767. doi: 10.1111/j.17447429.2009.00522.x

Gardner AL (2008) Mammals of South America. Volume 1. Marsupials, Xenarthrans, Shrews, and Bats. The University of Chicago Press, 669 pp. doi: 10.7208/chicago/9780226282428.001.0001

Hastriter MW (2012) Description of Wilsonipsylla spinicoxa, new genus and species of flea from Papua New Guinea and review of the suborder Pygiopsyllomorpha (Insecta: Siphonaptera). Annals of Carnegie Museum 81: 19-32. doi: 10.2992/007.081.0102

Hastriter MW, Eckerlin RP (2003) Jellisonia painter (Siphonaptera: Ceratophyllidae), a new species of flea from Guatemala. Annals of Carnegie Museum 72: 215-221.

Hastriter MW, Sage RD (2009) A description of two new species of Ectinorus (Siphonaptera: Rhopalopsyllidae) from Laguna Blanca National Park, Neuquén Province, Argentina. Proceedings of the Entomological Society of Washington 11: 581-597. doi: 10.4289/00138797-111.3.581

Hastriter MW, Sage RD (2011) Description of a new species of Ectinorus (E. spiculatus) (Siphonaptera, Rhopalopsyllidae) from Argentina and a review of the subgenus Ichyonus Smit, 1987. ZooKeys 124: 1-18.

Jayat JP, Ortiz PE (2010) Mamíferos del pedemonte de Yungas de la alta cuenca del río Bermejo en Argentina: una línea de base de diversidad. Mastozoología Neotropical 17: 69-86.

Johnson PT (1957) A classification of the Siphonaptera of South America. Memoirs of the Entomological Society of Washington 3: 1-298.

Jordan K (1931) Three new South American fleas. Novitates Zoologicae 36: 311-316.

Mardon DK (1981) An illustrated catalogue of the Rothschild collection of fleas (Siphonaptera) in the British Museum (Natural History). Volume VI. Pygiopsyllidae. Trustees of The British Museum (Natural History), London, 298 pp.

Ojeda RA, Barquez RM, Stadler J, Brandl R (2008) Decline of mammals species diversity along the Yungas forest of Argentina. Biotropica 40: 515-521. doi: 10.1111/j.17447429.2008.00401.x

Pacheco V (2015a) Genus Aepeomys. In: Patton JL, Pardiñas UFJ, D’Elía G (Eds) Mammals of South America - Volume 2, Rodents. The University of Chicago Press, Chicago, 574-577. 
Pacheco V (2015b) Genus Thomasomys. In: Patton JL, Pardiñas UFJ, D’Elía G (Eds) Mammals of South America - Volume 2, Rodents. The University of Chicago Press, Chicago, 617-683.

Pardiñas UFJ, Teta P, Alvarado-Serrano D, Geise L, Jayat JP, Ortiz PE, Concalves PR, D'Elia G (2015) Genus Akodon. In: Patton JL, Pardiñas UFJ, D’Elía G (Eds) Mammals of South America - Volume 2, Rodents. The University of Chicago Press, Chicago, 104-204.

Patton JL, Pardiñas UFJ, D’Elia G (2015) Mammals of South America. Volume 2: Rodents. The University of Chicago Press, Chicago, 1834 pp.

Percequillo AR (2015a) Genus Aegialomys. In: Patton JL, Pardiñas UFJ, D’Elía G (Eds) Mammals of South America - Volume 2, Rodents. The University of Chicago Press, Chicago, 293-298.

Percequillo AR (2015b) Genus Nephelomys. In: Patton JL, Pardiñas UFJ, D’Elía G (Eds) Mammals of South America - Volume 2, Rodents. The University of Chicago Press, Chicago, 377-390.

Rothschild M, Traub R (1971) A revised glossary of terms used in the taxonomy and morphology of fleas. An illustrated catalogue of the Rothschild collection of fleas (Siphonaptera) in the British Museum (Natural History). The British Museum (Natural History), London, 8-85. Sanchez J, Lareschi M (2014) Two new species of Neotyphloceras (Siphonaptera: Ctenophthalmidae) from Argentinean Patagonia. Zootaxa 3784: 159-170. doi: 10.11646/ zootaxa.3784.2.5

Steppan SJ, Ramirez O (2015) Genus Phyllotis. In: Patton JL, Pardiñas UFJ, D’Elía G (Eds) Mammals of South America - Volume 2, Rodents. The University of Chicago Press, Chicago, 535-554.

Timm RM, Patterson BD (2008) Genus Caenolestes. In: Gardner AL (Ed.) Mammals of South America - Volume 1, Marsupials, Xenarthrans, Shrews, and Bats. The University of Chicago Press, Chicago, 120-124.

Tipton VJ, Machado Allison CE (1972) Fleas of Venezuela. Brigham Young University Science Bulletin, Biological Series 17: 1-115.

Tribe CJ (2015) Genus Rhipidomys. In: Patton JL, Pardiñas UFJ, D’Elía G (Eds) Mammals of South America - Volume 2, Rodents. The University of Chicago Press, Chicago, 583-611.

Voss R (2015) Tribu Ichthyomyini. In: Patton JL, Pardińas UFJ, D’Elía G (Eds) Mammals of South America - Volume 2, Rodents. The University of Chicago Press, Chicago, 279-291. 